\title{
Do women fare worse? A metaanalysis of gender differences in outcome after traumatic brain injury
}

\author{
Elana Farace, Ph.D., and Wayne M. Alves, Ph.D. \\ Department of Neurosurgery, University of Virginia; and INC Research, Charlottesville, Virginia
}

\begin{abstract}
The purpose of this metaanalysis was to investigate possible gender differences in TBI sequelae. The case fatality rates in patients after TBI have previously been shown to be significantly higher in women as compared with men. A quantitative review of published studies of TBI outcome revealed eight studies (20 outcome variables) of TBI in which outcome was reported separately for men and women. Outcome was worse in women than in men for $85 \%$ of the measured variables, with an average effect size of -0.15 . Although clinical opinion is often that women tend to experience better outcomes than do men after TBI, the opposite pattern was suggested in the results of this metaanalysis. However, this conclusion is limited by the fact that in only a small percentage of the total published reports on TBI outcome was outcome described separately for each sex. A careful, prospective study of sex differences in TBI outcome is clearly needed.
\end{abstract}

KEY WORDS • brain injury • gender difference - metaanalysis • outcome study

Injury is the leading cause of death from birth to age 45 years, resulting in more than 56,000 deaths annually, and TBI is responsible for the majority of these deaths. ${ }^{23}$ In the entire U.S. population there are at least 373,000 new cases of TBI each year that require hospitalization. ${ }^{26}$ This figure is likely to be an underestimation of total new TBI cases per year, because it under-samples the patients who sustain milder TBI and who are never hospitalized. Approximately 99,000 new survivors of TBI each year are classified as disabled. ${ }^{26}$ Survivors of TBI tend to be young, which means that there is a high life-long cost of disability. Traumatic brain injury is estimated to create a yearly expenditure of $\$ 48.3$ billion dollars. $^{2}$

The sex of patients with TBI has long been overlooked as a possible explanation for, or confounding factor in, outcomes after TBI. However, what little research exists on gender differences in TBI outcome suggests that outcome may be worse in women than in men. For example, Klauber and colleagues ${ }^{22}$ reported that case fatality rates were elevated in women as compared with men in two age groups. Kraus and colleagues ${ }^{25}$ have recently reported findings from the UCLA Brain Injury Research Center, in which case fatality rates at the Emergency Department (while in the intensive care unit and after leaving it) were shown to be significantly higher for women compared with men. In addition, the rate of poor outcomes (that is, death, persistent vegetative state, and severe disability)

Abbreviations used in this paper: $\mathrm{IQ}=$ intelligence quotient, $\mathrm{SS}$ $=$ sums of squares, TBI = traumatic brain injury. was significantly elevated for women compared with men at $6,12,18$ months postdischarge. Bazarian and cowork$\mathrm{ers}^{4}$ recently reported that female gender was a significant predictor of the development of postconcussive symptoms at 1 month after suffering mild TBI.

In TBI research, gender is likely to interact with many other outcome variables. If gender interactions are not understood, they may end up obscuring true findings in TBI research. For example, sex differences in the metabolism of a pharmacological intervention (such as, tirilazad ${ }^{18}$ ) may obscure true treatment effects. The sex of the patient may be a very important risk factor of TBI outcome. The purpose of this paper is to perform a quantitative, metaanalytic review of the outcome in TBI literature to provide a preliminary evaluation of the influence of gender on outcome after TBI.

\section{EPIDEMIOLOGY: TBI IS NOT JUST A YOUNG MAN'S DISEASE}

Gender differences in the incidence of TBI are well known. The authors of epidemiological studies have established that many more men than women sustain a TBI. ${ }^{35}$ Kraus and Nourjah ${ }^{24}$ studied patients hospitalized in 1981 for mild head injury (Glasgow Coma Scale scores of 13-15) and found that the incidence was approximately twice as high in male as in female patients (174.7 and 85.2 , respectively, per 100,000$)$. In a different study the investigators found that in men under age 65 years the rate of head injury was almost three times as high (1141 [73\%] of 1571) as in women (430 [27\%] of 1571) in a Scottish 
sample of head-injured patients. ${ }^{33}$ It is important to note that although men sustain a greater number of TBIs than women, women still compromise a substantial portion of TBI patients (one quarter to one third of the population according to these estimates).

The gender difference found in the incidence of TBI is only seen from puberty until middle age, leaving a large part of the life span with roughly equal rates of TBI between the sexes. In several studies it has been shown that there are no gender differences in the incidence of children sustaining TBI. ${ }^{14,16}$ In adults the incidence of TBI appears to be approximately the same in men and women aged 45 to 75 . In older patients (65 years of age or older) no gender shown differences have been shown in the rate of TBI, with a sex ratio of $49 \%$ men and $51 \%$ women. ${ }^{33}$ After age 75 years, there is a slightly higher incidence of mild head injury in women, due mostly to falls. ${ }^{24,33}$

The sex of the patient may in fact be a very important determinant of TBI outcome. However, to our knowledge, there is only one published report specifically designed to study the effect of sex on TBI outcome. ${ }^{20}$ Therefore, a thorough, metaanalytic review could help to elucidate possible gender differences in TBI outcome and to identify important gaps in our knowledge regarding recovery and outcome after brain injury. Based on the available evidence for predictors of outcome in TBI, the following questions were formulated. 1) Is there a gender difference in TBI outcome, and if so, what is the magnitude of that difference? 2) Does a gender difference depend on the specific outcome measure?

\section{CLINICAL MATERIAL AND METHODS}

\section{Selection of Studies}

The procedures for performing a metaanalysis outlined by Glass, et al., ${ }^{12}$ were followed. The published Englishlanguage literature on TBI outcome was reviewed. Studies were included if they were published in a peer-reviewed journal or an edited book and were published before January 1998. Studies were required to include patients who had suffered TBI and at least one outcome measure was reported separately for men and women. Patients were required to be 12 years of age or older.

An initial search on Medline resulted in 16,302 references for "brain injuries," limited to 9822 for English-language articles. Adding "sex or gender" reduced the number to 40 references, most of which had been selected because the statement "age and sex-matched controls" was included. These 40 studies were reviewed to determine if they reported results separately for each sex. In one study in which data were reported separately by $\operatorname{sex}^{39}$ there was considerable bias in its methodology, and it was excluded (the outcome measure was spouses' perceptions of change in the patients' sexual behavior, in a sex-segregated Indian culture wherein only two wives spoke about their husbands, but all the husbands spoke about their wives' behavior). The sample of manuscripts was therefore limited to eight studies, $5,7,20,21,27,30,38,45$ which, together, contained 20 variables for which outcome in men and women was reported separately.

\section{Selection of Variables for Analysis}

To be included, each study was required to report any designated outcome variable and the total numbers of male and female TBI patients with the given outcome. Either the number of men and women in whom the outcome variable was reported (allowing for a chi-square analysis), or an F-statistic for differences between groups, was required to allow for calculation of an effect size. All outcome variables meeting these criteria from each study were included for analysis.

To examine the questions posed in this study, a set of explanatory variables was selected based on the availability of reported data. First, outcome variables were classified into "outcome category" to allow for comparison across similar outcomes (indices of initial injury severity, somatic/ postconcussive complaints, return to work, and new psychiatric symptoms). When the outcome variable was reported in the study as a positive outcome (for example, "return to work"), the direction of the variable was reversed to reflect a negative outcome (for example, "no return to work"). This reversal allowed better cross-variable comparison because almost all outcome variables were expressed as a negative outcome.

\section{Statistical Analysis}

Effect size ${ }^{6}$ was computed for each comparison between men and women on the given outcome variable. If the variable was reported only as the number of men and women in each group, we performed chi-square analysis of the observed as compared with the expected numbers of men and women in whom the outcome variable was reported. When insufficient descriptive statistics were provided, the effect size was computed from inferential statistics $(\mathbf{F})$ according to formulas provided by Glass, et al. ${ }^{12}$ Each of these effect size indices will be described.

The chi-square effect size index (w) was calculated according to the procedures of Cohen. ${ }^{6}$ This effect size index is used to measure the discrepancy between the observed and expected proportions of the two groups (in this analysis, men and women) by using the following formula:

$$
w=\sqrt{\sum \frac{(O-E)^{2}}{E}}
$$

Where ' $O$ ' refers to the observed frequency and ' $E$ ' to the expected frequency ${ }^{17}$ of men and women in these groups.

The $\mathbf{F}$ statistic effect size (f) was also estimated according to the procedures of Cohen. ${ }^{6}$ This estimation was performed by working from the $\mathbf{F}$ statistic such that the SS and mean square error were estimated from the means of the outcome variables and the numbers of men and women in a two-way analysis of variance (for further explanation see Howell, ${ }^{17}$ pp 306-314). Eta is used to represent effect size calculated from an $\mathbf{F}$ statistic. Eta squared is then calculated by the group SS divided by SS total. The effect size index $\mathbf{f}$ is then calculated using the following formula: ${ }^{6}$ 


$$
f=\sqrt{\frac{e t \sigma^{2}}{1-e t \sigma^{2}}}
$$

Table 1 provides a summary of the results of these effect-size analyses, and Table 2 provides a summary of the effect sizes by gender collapsed across different outcome variables.

\section{RESULTS}

The first finding of interest in this metaanalysis was the small number of studies available for inclusion. The primary literature on TBI outcomes is obviously much larger than that represented by the studies included in this metaanalysis, but we included only in which results were reported separately for men and women.

\section{Worse Outcome in Women}

On average, outcome after TBI was found to be worse in women than in men, regardless of the variable being analyzed (see Table 1). How much worse did women really fare? As is shown in Fig. 1, in 17 (85\%) of 20 outcome variables classified by sex, outcome after TBI was worse in women across all brain-injury types. A nonparametric test of "goodness of fit" that allows for nonindependence of observations (Kolmogorov-Smirnov one-sample test) was performed to compare the likelihood that a worse outcome in women would be shown only by chance. Analysis of the results indicated that the outcome gender ratios reported in Table 1 were very unlikely to happen by chance $(\mathrm{p}<0.05)$.

\section{Magnitude of Effect Sizes}

To understand the magnitude of these gender differences in TBI outcome, Table 1 includes the effect sizes of the gender differences at the study level. According to Cohen, ${ }^{6} 0.1$ can be considered a small effect size, 0.3 a medium effect size, and 0.5 a large effect size. The mean effect size for this metaanalysis was -0.15 (the negative sign indicates women having worse outcome).

As can be seen in Table 1, the largest effect size was found for having one or more postconcussive symptoms at 6 weeks, ${ }^{38}$ with small to medium effect sizes shown for headache, ${ }^{7,20}$ dizziness ${ }^{7}$ insomnia, ${ }^{7}$ no return to work,, 30 days of posttraumatic amnesia, ${ }^{21}$ and length of hospitalization. Outcomes were significantly worse in women (significance calculated within studies) than they were in men with regard to all of these outcome variables except one: no return to work. ${ }^{30}$ When gender differences were investigated by types of outcome measures (Table 2), women's effect sizes ranged from -0.17 to -0.32 , indicating worse outcomes in women than men in every outcome category except return to work. ${ }^{30}$ The results of the study reported by McMordie, et al., ${ }^{30}$ are difficult to explain, considering the fact that in the same study women were found to have sustained more days of loss of consciousness (mean 42.83 days for men and 45.94 days for women). It is interesting to note that this study also had the longest length of time from injury to assessment (mean
6.7 years), perhaps suggesting an interaction of gender with outcome over time.

\section{DISCUSSION}

In general, it appears that outcomes may be worse in women than in men after TBI. However, it should be noted that only a small percentage of the published literature on outcome after TBI was sampled for this metaanalysis, because outcome data were rarely classified by sex. One potential source of bias in any metaanalysis is the editorial bias against publishing negative studies. Thus, it may have been that only in studies with surprising differences between the sexes was data reported separately by sex. However, the rarity of studies reporting data separately for each sex, whether or not the outcome differences were significant, suggests that gender has simply not been previously considered to be an important risk factor in TBI outcome.

What might be the source of a sex difference in TBI outcome? Factors such as length of time from injury to the emergency room, age, premorbid functioning, location of damage within the brain, and type of lesion produced, ${ }^{10}$ that influence TBI outcome are expected to vary randomly in a population, and, therefore, are not expected to produce a sex difference in TBI outcome. However, some of these factors potentially do correlate or interact with TBI patient gender and may therefore relate to a difference in outcome. For example, men and women who sustain brain injuries may differ premorbidly. Traumatic brain injury sequelae may be reported differently. Women may sustain different injuries, due to morphological differences or to different causes of trauma. Established sex differences in cognitive ability and psychosocial factors may also play a role, as may differences in functional brain organization. Sex hormones may affect outcome after TBI. Different treatments may affect men and women differently. A discussion of each of these possibilities follows.

\section{Premorbid Factors}

Given that fewer women than men sustain TBI, perhaps the women who do suffer TBI differ systematically from the overall population. For example, do men and women who sustain a TBI differ in premorbid IQ? Premorbid IQ is a significant predictor of TBI outcome, ${ }^{13,46}$ given survival. Sex differences may also exist in premorbid psychosocial factors such as family function, ${ }^{34}$ problem-solving skills, ${ }^{34}$ education, ${ }^{11}$ employment, ${ }^{15}$ socioeconomic status,,${ }^{15,44}$ and medical insurance, ${ }^{44}$ all of which have been shown to be significant predictors of outcome after TBI, although sex differences in these factors have not yet been tested in the TBI population.

\section{Symptom Reporting}

Sex differences in TBI outcome may result from the different ways in which the two sexes report illness and symptoms. Indeed, more women report illnesses and make more physician visits per person each year than men. ${ }^{3,47}$ It may be easier for women to admit to having symptoms such as headaches, fatigue, anxiety, or depression (see Table $1^{7}$ ) than men. When an outcome variable is subjective and/or nonspecific, such as fatigue ${ }^{45}$ (see Table 1), a difference in 
TABLE 1

GENDER DIFFERENCES IN TBI OUTCOME*

\begin{tabular}{|c|c|c|c|c|c|c|c|}
\hline Authors \& Year & $\begin{array}{l}\text { Outcome } \\
\text { Variable }\end{array}$ & $\begin{array}{c}\text { TBI } \\
\text { Severity/Type }\end{array}$ & $\begin{array}{l}\text { Time } \\
\text { Since } \\
\text { Injury }\end{array}$ & $\begin{array}{l}\text { No. in Study/ } \\
\text { No. Reporting } \\
\text { Symptom }\end{array}$ & $\begin{array}{l}\text { Statistical } \\
\text { Analysis }\end{array}$ & $\begin{array}{l}\text { Effect } \\
\text { Sizeł }\end{array}$ & $\begin{array}{l}\text { Worse } \\
\text { Outcome }\end{array}$ \\
\hline \multicolumn{8}{|c|}{ initial injury severity } \\
\hline $\begin{array}{l}\text { Wilberger, } \\
\text { et al., } 1990\end{array}$ & death & $\begin{array}{c}\text { GCS 3-7, } \\
\text { ASDH }\end{array}$ & $18 \mathrm{mos}$ & $\begin{array}{l}\text { M } 77 / 50 \\
\text { F } 24 / 17 \\
\text { total } 101\end{array}$ & $X^{2}=0.29$ & $w=-0.10$ & women \\
\hline \multirow[t]{2}{*}{$\begin{array}{l}\text { Kaplan \& } \\
\text { Corrigan, } 1992\end{array}$} & days of PTA & $\begin{array}{l}\text { CHI w/ } \\
\text { some PTA }\end{array}$ & $\begin{array}{l}\text { chart } \\
\text { review }\end{array}$ & $\begin{array}{l}\text { M } 62 \\
\text { F } 26 \\
\text { total } 88\end{array}$ & $F=4.02 \dagger$ & $f=-0.22$ & women \\
\hline & $\begin{array}{l}\text { length of } \\
\text { hospital- } \\
\text { ization }\end{array}$ & $\begin{array}{l}\text { CHI w/ } \\
\text { some PTA }\end{array}$ & $\begin{array}{l}\text { chart } \\
\text { review }\end{array}$ & $\begin{array}{l}\text { M } 62 \\
\text { F } 26 \\
\text { total } 88\end{array}$ & $F=3.51$ & $f=-0.20$ & women \\
\hline \multicolumn{8}{|c|}{ somatic/ PCS complaints } \\
\hline $\begin{array}{l}\text { Rutherford, } \\
\text { et al., } 1977\end{array}$ & $\begin{array}{l}\geq 1 \text { postcon- } \\
\text { cussive } \\
\text { symptom }\end{array}$ & $\begin{array}{l}\text { minor CHI } \\
\text { w/ con- } \\
\text { cussion; } \\
\text { no op }\end{array}$ & 6 wks & $\begin{array}{l}\text { M 92/37 } \\
\text { F 53/37 } \\
\text { total } 145\end{array}$ & $X^{2}=11.79 \dagger$ & $w=-0.43$ & women \\
\hline \multirow[t]{8}{*}{$\begin{array}{l}\text { Edna \& Cap- } \\
\text { pelen, } 1987\end{array}$} & $\begin{array}{l}\text { impaired } \\
\text { memory }\end{array}$ & $\begin{array}{l}\text { GCS 3-15, } \\
\text { CHI w/ LOC } \\
\text { or skull fx } \\
\text { or ICH }\end{array}$ & $3-5$ yrs & $\begin{array}{l}\text { M } 351 / 68 \\
\text { F } 134 / 31 \\
\text { total } 485\end{array}$ & $X^{2}=0.84$ & $f=-0.07$ & women \\
\hline & dizziness & $\begin{array}{l}\text { GCS 3-15, } \\
\text { CHI w/ LOC } \\
\text { or skull fx } \\
\text { or ICH }\end{array}$ & $3-5$ yrs & $\begin{array}{l}\text { M } 351 / 48 \\
\text { F } 134 / 42 \\
\text { total } 485\end{array}$ & $X^{2}=20.03 \dagger$ & $w=-0.35$ & women \\
\hline & fatigue & $\begin{array}{l}\text { GCS 3-15, } \\
\text { CHI w/ LOC } \\
\text { or skull fx } \\
\text { or ICH }\end{array}$ & $3-5$ yrs & $\begin{array}{l}\text { M } 351 / 61 \\
\text { F } 134 / 28 \\
\text { total } 485\end{array}$ & $X^{2}=0.80$ & $w=-0.07$ & women \\
\hline & $\begin{array}{l}\text { irritability } \\
\text { (noise, } \\
\text { light) }\end{array}$ & $\begin{array}{l}\text { GCS 3-15, } \\
\text { CHI w/ LOC } \\
\text { or skull fx } \\
\text { or ICH }\end{array}$ & $3-5$ yrs & $\begin{array}{l}\text { M } 351 / 56 \\
\text { F } 134 / 32 \\
\text { total } 485\end{array}$ & $X^{2}=4.10^{*}$ & $w=-0.16$ & women \\
\hline & $\begin{array}{l}\text { impaired } \\
\text { concen- } \\
\text { tration }\end{array}$ & $\begin{array}{l}\text { GCS 3-15, } \\
\text { CHI w/ LOC } \\
\text { or skull fx } \\
\text { or ICH }\end{array}$ & $3-5$ yrs & $\begin{array}{l}\text { M } 351 / 46 \\
\text { F } 134 / 22 \\
\text { total } 485\end{array}$ & $X^{2}=0.88$ & $w=-0.07$ & women \\
\hline & insomnia & $\begin{array}{l}\text { GCS 3-15, } \\
\text { CHI w/ LOC } \\
\text { or skull fx } \\
\text { or ICH }\end{array}$ & $3-5$ yrs & $\begin{array}{l}\text { M } 351 / 38 \\
\text { F } 134 / 27 \\
\text { total } 485\end{array}$ & $X^{2}=7.26^{\star}$ & $w=-0.21$ & women \\
\hline & tinnitus & $\begin{array}{l}\text { GCS 3-15, } \\
\text { CHI w/ LOC } \\
\text { or skull fx } \\
\text { or ICH }\end{array}$ & $3-5$ yrs & $\begin{array}{l}\text { M } 351 / 45 \\
\text { F } 134 / 16 \\
\text { total } 485\end{array}$ & $X^{2}=0.07$ & $w=0.02$ & men \\
\hline & $\begin{array}{r}\text { hearing } \\
\text { defect }\end{array}$ & $\begin{array}{l}\text { GCS 3-15, } \\
\text { CHI w/ LOC } \\
\text { or skull fx } \\
\text { or ICH }\end{array}$ & $3-5$ yrs & $\begin{array}{l}\text { M } 351 / 42 \\
\text { F } 134 / 9 \\
\text { total } 485\end{array}$ & $X^{2}=2.84$ & $w=0.13$ & men \\
\hline
\end{tabular}

"outcome" between male and female patients may simply be the result of the way in which the sexes report behavior. However, when the outcome variable is a more objective measure, such as a test score, or is an irrefutable measure, such as death ${ }^{45}$ (Table 1), outcome is unlikely to be related to symptom-reporting behavior.

\section{Injury Factors}

Outcome after TBI may differ in men and women because of gender-related behavioral patterns that cause the traumatic accident. There is a great deal of evidence that men, especially young men, engage in risk-taking behavior far more frequently than women (see, for example, the studies by Morrongiello and Rennie ${ }^{31}$ and Zimbardo, et al. $\left.{ }^{48}\right)$. According to the National Highway Traffic Safety Administration, ${ }^{32}$ men are more than twice as likely to be the driver in fatal car crashes, and women are more likely to be the passenger in a car crash. Men and women differ in safety-related activity such as using a seatbelt or wearing a helmet. The National Highway Traffic Safety Administration study reported seatbelt use in $68 \%$ of women and $56.8 \%$ of men in 1996. Women may experience worse outcomes after TBI because they are more likely to wear seatbelts and helmets and perhaps the use of safety restraints changes the site of impact or increases the severity needed to cause an injury.

\section{Cognition and Psychosocial Factors}

If women have worse outcomes than men after TBI, why is this effect not globally recognized? One possibility is that the worse outcomes reported in women may have been masked by women's relative strength in verbal fluency ability, which has been shown in a metaanalysis to have a medium effect size. ${ }^{19}$ When functional criteria for discharge requires that a patient be able to ambulate and communicate, women's superior verbal fluency, even af- 
TABLE 1, CONTINUED

GENDER DIFFERENCES IN TBI OUTCOME*

\begin{tabular}{|c|c|c|c|c|c|c|c|}
\hline Authors \& Year & $\begin{array}{l}\text { Outcome } \\
\text { Variable }\end{array}$ & $\begin{array}{c}\text { TBI } \\
\text { Severity/Type }\end{array}$ & $\begin{array}{l}\text { Time } \\
\text { Since } \\
\text { Injury }\end{array}$ & $\begin{array}{l}\text { No. in Study/ } \\
\text { No. Reporting } \\
\text { Symptom }\end{array}$ & $\begin{array}{l}\text { Statistical } \\
\text { Analysis }\end{array}$ & $\begin{array}{l}\text { Effect } \\
\text { Size‡ }\end{array}$ & $\begin{array}{c}\text { Worse } \\
\text { Outcome }\end{array}$ \\
\hline \multirow[t]{2}{*}{$\begin{array}{l}\text { Edna \& Cap- } \\
\text { pelen, } 1987 \\
\text { (continued) }\end{array}$} & $\begin{array}{l}\text { double } \\
\text { vision }\end{array}$ & $\begin{array}{l}\text { GCS 3-15, } \\
\text { CHI w/ LOC } \\
\text { or skull fx } \\
\text { or ICH }\end{array}$ & $3-5$ yrs & $\begin{array}{l}\text { M } 3518 \\
\text { F 134/4 } \\
\text { total 485 }\end{array}$ & $X^{2}=0.20$ & $w=-0.04$ & women \\
\hline & headache & $\begin{array}{l}\text { GCS 3-15, } \\
\text { CHI w/ LOC } \\
\text { or skull fx } \\
\text { or ICH }\end{array}$ & $3-5$ yrs & $\begin{array}{l}\text { M 351/62 } \\
\text { F 134/51 } \\
\text { total } 485\end{array}$ & $X^{2}=22.57 \dagger$ & $w=-0.37$ & women \\
\hline $\begin{array}{l}\text { Jensen \& } \\
\quad \text { Nielsen, } 1990\end{array}$ & headache & $\begin{array}{l}\text { LOC }<24 \text { hrs, } \\
\text { concussion }\end{array}$ & $9-12$ mos & $\begin{array}{l}M 96 / 52 \\
F ~ 72 / 56 \\
\text { total } 168\end{array}$ & $x^{2}=9.99 \dagger$ & $w=-0.35$ & women \\
\hline \multicolumn{8}{|l|}{ return to work } \\
\hline $\begin{array}{l}\text { McMordie, } \\
\text { et al., } 1990\end{array}$ & $\begin{array}{c}\text { no return } \\
\text { to work }\end{array}$ & any TBI & $x=6.7 y r s$ & $\begin{array}{l}\text { M 138/832 } \\
\text { F 39/14 } \\
\text { total } 177\end{array}$ & $x^{2}=7.22 \dagger$ & $w=0.39$ & men \\
\hline $\begin{array}{l}\text { Cifu, et al., } \\
1997\end{array}$ & $\begin{array}{c}\text { no return } \\
\text { to work }\end{array}$ & any TBI & $1 \mathrm{yr}$ & $\begin{array}{l}\text { M 106/64 } \\
\text { F 26/19 } \\
\text { total } 132\end{array}$ & $X^{2}=1.44$ & $w=-0.22$ & women \\
\hline \multicolumn{8}{|c|}{ new psychiatric symp } \\
\hline \multirow[t]{2}{*}{$\begin{array}{l}\text { Edna \& Cap- } \\
\text { pelen, } 1987\end{array}$} & anxiety & $\begin{array}{l}\text { GCS 3-15, } \\
\text { CHI w/ LOC } \\
\text { or skull fx } \\
\text { or ICH }\end{array}$ & $3-5$ yrs & $\begin{array}{l}\text { M } 351 / 21 \\
\mathrm{~F} 134 / 16 \\
\text { total } 485\end{array}$ & $X^{2}=4.88 \dagger$ & $w=-0.17$ & women \\
\hline & depression & $\begin{array}{l}\text { GCS 3-15, } \\
\text { CHI w/ LOC } \\
\text { or skull fx } \\
\text { or ICH }\end{array}$ & $3-5$ yrs & $\begin{array}{l}\text { M 351/27 } \\
\text { F 134/18 } \\
\text { total 485 }\end{array}$ & $X^{2}=3.80$ & $w=-0.15$ & women \\
\hline $\begin{array}{l}\text { Levin, et al., } \\
1987\end{array}$ & depression & any $\mathrm{TBI}$ & $\begin{array}{r}\text { at least } \\
6 \text { mos }\end{array}$ & $\begin{array}{l}\text { M } 78 \\
\text { F } 23 \\
\text { total } 101\end{array}$ & $F=13.77$ & $f=-0.37$ & women \\
\hline
\end{tabular}

*Abbreviations: $\mathrm{ASDH}=$ acute subdural hematoma; $\mathrm{CHI}=$ closed head injury; $f$ = effect size index for $\mathrm{F}$ statistic; $\mathrm{fx}=$ fracture; $\mathrm{GCS}=\mathrm{glasgow}$ coma scale; $\mathrm{ICH}=$ intracranial hemorrhage; $\mathrm{LOC}=$ loss of consciousness; PTA = posttraumatic amnesia; $w=$ chi-square effect size index.

t $p<0.05$

$\ddagger$ See Magnitude of Effect Sizes for definitions.

ter brain injury, may falsely cause their outcome to appear better than it actually is. In these cases, women's strengths may be limited to speaking ability, with significant performance and/or functional deficits remaining undetected. This effect may cause an overestimation of women's true level of function by their caretakers and physicians, and it may result in women being discharged before sufficient recovery, leading to worse outcome.

\section{Gender Differences in Brain Function}

Analysis of a growing body of evidence demonstrates that men's and women's brains differ in functional organization (see Farace \& Turkheimer ${ }^{9}$ for review). In studies of unilateral lesions in stroke patients ${ }^{42,43}$ women have been shown to have more bilateral representation of Verbal and Performance IQ than men. This bilateral representation of verbal skills (spatial skills were not tested) has also been supported by the results of a functional magnetic resonance imaging study in which the authors found that women possessed greater bilateral verbal-processing ability in a lexical decision task than men. ${ }^{41}$ It is possible that a sex difference in brain organization relates to a sex difference in TBI outcome. Perhaps diffuse brain injury in TBI has a greater chance of affecting relevant function in women's brains because there is a greater chance of the injury affecting a brain area, whereas men's more focally organized brains may be relatively spared.

\section{Sex Hormones and TBI Sequelae}

An interaction of TBI sequelae with sex hormones may relate to differences in TBI outcome between men and women. Alkayed, et al., ${ }^{1}$ have found that estrogen had a protective effect against ischemia in female rats in which they used an experimental stroke paradigm. However, in an experimental brain trauma study, the authors found a protective effect of estrogen (improvement in free magnesium concentration, cytosolic phosphorylation potential, and motor function) only in male rats. Lowered cytosolic phosphorylation potential after trauma and higher mortality rates were demonstrated in all groups of female rats.[8] Progesterone has also been shown to have a protective effect in reducing brain edema in TBI sequelae in female rats. ${ }^{37}$ In progesterone-treated male and female rats a reduction in behavioral impairment and reduced neuronal degeneration 21 days after injury were also demonstrated. ${ }^{36}$ A potential negative effect of sex hormones, especially estrogen, may lead to a worse outcome in women after TBI.

\section{Treatment Effects}

Differences in metabolism between the sexes also have potential effects on TBI brain sequelae and interactions with pharmacological treatment. For example, there is a striking gender-related difference reported in a study of the pharmacokinetics of tirilazad, ${ }^{18}$ a neuroprotective agent recently investigated for prevention of ischemia-re- 


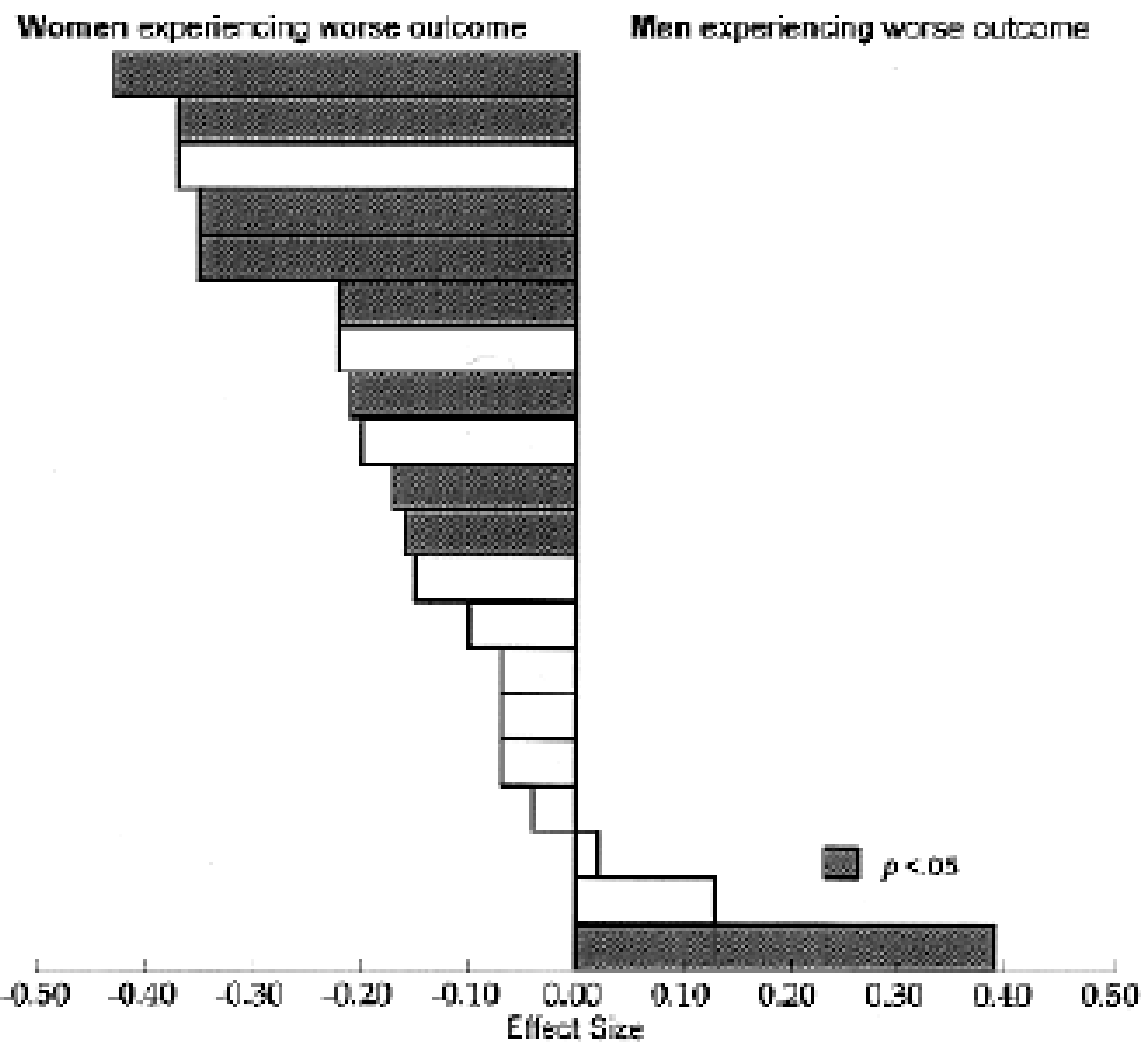

Fig. 1. Graph displaying effect sizes of TBI outcome measures for 20 outcome variables that were reported separately for each sex. Shaded bars indicate a reported significant statistical difference. Bars extending to the right indicate variables for which men had worse outcome, and bars extending to the left indicate variables for which women had worse outcome.

lated neuronal damage after TBI. ${ }^{28,29}$ Tirilazad clearance was approximately $40 \%$ higher in young women than in young men. ${ }^{18}$ Therefore, if the agent did have a beneficial effect overall, due to increased metabolism in women there may not have been a sufficient amount of the drug to have an effect.

Evidence for sex-related differences in brain metabolism can also be seen in a recent study of alpha 2-receptor by using positron emission tomography. ${ }^{40}$ The authors found that global increases in metabolism in response to norepinephrine treatment were revealed in women whereas none were demonstrated in men. ${ }^{40}$

\section{Importance of the Problem: Clinical and Research}

Because either most TBI research has been performed only in men or the data have not been analyzed or reported separately by sex, clinicians have very little data to

TABLE 2

AVERAGE EFFECT SIZES BY SEX FOR DIFFERENT OUTCOME MEASURES

\begin{tabular}{lcccl}
\hline \hline \multicolumn{1}{c}{ Outcome Category } & $\begin{array}{c}\text { No. of } \\
\text { Studies }\end{array}$ & $\begin{array}{c}\text { No. of } \\
\text { Outcomes }\end{array}$ & $\begin{array}{c}\text { No. of } \\
\text { Different } \\
\text { Cases }\end{array}$ & $\begin{array}{l}\text { Average } \\
\text { Effect Size }\end{array}$ \\
\hline $\begin{array}{l}\text { initial injury severity } \\
\text { somatic/PCS complaints }\end{array}$ & 3 & 3 & 189 & $\begin{array}{l}\text { women }=-0.17 \\
\text { women }=-0.032\end{array}$ \\
return to work & 3 & 11 & 798 & $\begin{array}{l}\text { men }=0.07 \\
\text { women }=-0.22\end{array}$ \\
new psychiatric symptoms & 2 & 1 & 309 & $\begin{array}{l}\text { men }=0.39 \\
\text { women }=-0.23\end{array}$ \\
\hline
\end{tabular}


guide the management of women who sustain a TBI. The incidence of TBI in women may be increasing, as women participate in more sports and other TBI-risky behaviors. Thus, a public health dilemma is potentially developing, in which practitioners may be faced with increasing numbers of women with TBI but will have scarce data to guide treatment. Endocrine system and metabolic differences may interact with TBI treatment in ways not understood. There may be a potential gender bias in referral and treatment, which means female TBI patients may not be treated as effectively as men.

Traumatic brain injury is a difficult disease to study because it is a very heterogeneous phenomenon. Therefore, a great deal of "noise" will likely persist in treatment-focused research. Interactions between TBI treatment and sex may obscure results, as may have partly been the case with tirilazad. Every reasonable effort should be undertaken to reduce this noise so as to obtain a clearer picture of the true treatment effects and recovery mechanisms. Gender is one source of this noise that can be easily identified and reported, which has been shown to have measurable effects. In TBI studies, data should be reported separately by sex, and adjusted analyses should be performed.

\section{CONCLUSIONS}

In only a small percentage of the total published literature on TBI outcome are results separated by sex, but a quantitative review of those studies reveals that worse outcomes are demonstrated in women after TBI overall. This sex difference may have implications for TBI prevention and rehabilitation efforts. Further examination is clearly needed.

If a sex-related difference in TBI outcome is found to be stable, future studies should endeavor to answer whether the difference in outcome stems from differences in mechanism (of the accident or in the brain), from treatment variables, or from premorbid sex differences. It is clear that a careful, prospective study of the natural history of TBI mechanisms and sequelae is needed to determine the relation of gender differences to TBI outcome. Traumatic brain injury outcome data should be reported separately by sex, and adjusted outcomes analyses should be conducted with gender as a covariate. The potentially worse outcomes in women after TBI should increase awareness of the fact that women not only do sustain TBI but may potentially be more seriously affected than previously thought.

\section{References}

1. Alkayed NJ, Harukami I, Kimes AS, et al: Gender-linked brain injury in experimental stroke. Stroke 29:159-166, 1998

2. Anonymous: Guidelines for the Management of Severe Head Injury. A Joint Initiative of the Brain Trauma Foundation, The American Association of Neurological Surgeons, The Joint Section on Neurotrauma and Critical Care. Washington, DC: Brain Injury Assocation, 1995

3. Apfel RJ: How are women sicker than men? An overview of psychosomatic problems in women. Psychother Psychom 37: 106-118, 1982

4. Bazarian JJ, Wong T, Harris M, et al: Epidemiology and predictors of post-concussive syndrome after minor head injury in an emergency population. Brain Inj 13:173-189, 1999
5. Cifu DX, Keyser-Marcus L, Lopez E, et al: Acute predictors of successful return to work 1 year after traumatic brain injury: a multicenter analysis. Arch Phys Med Rehabil 78:125-131, 1997

6. Cohen J: Statistical Power Analysis for the Behavioral Sciences, ed 2. Hillsdale, NJ: L. Erlbaum Associates, 1988

7. Edna TH, Cappelen J: Late post-concussional symptoms in traumatic brain injury. An analysis of frequency of risk factors. Acta Neurochir 86:12-17, 1987

8. Emerson CS, Headrick JP, Vink R: Estrogen improves biochemical and neurologic outcome following traumatic brain injury in male rats, but not in females. Brain Res 608:95-100, 1993

9. Farace E, Turkheimer E: Gender differences in bria morphometry and function, in Bigler ED (ed): Neuroimaging. Handbook of Brain Function. New York: Plenum, 1996, pp 127-151

10. Gennarelli TA, Spielman GM, Langfitt TW, et al: Influence of the type of intracranial lesion on outcome from severe head injury. J Neurosurg 56:26-32, 1982

11. Girard D, Brown J, Burnett-Stolnack M, et al: The relationship of neuropsychological status and productive outcomes following traumatic brain injury. Brain Inj 10:663-676, 1996

12. Glass GV, McGaw B, Smith ML: Meta-Analysis in Social Research. Beverly Hills: Sage Publications, 1981

13. Grafman J, Salazar A, Weingartner H, et al: The relationship of brain-tissue loss volume and lesion location to cognitive deficit. J Neuroscie 6:301-307, 1986

14. Hahn YS, Fuchs S, Flannery AM, et al: Factors influencing posttraumatic seizures in children. Neurosurgery 22:864-867, 1988

15. Harrison-Felix C, Zafonte R, Mann N, et al: Brain injury as a result of violence: preliminary findings from the traumatic brain injury model system. Arch Phys Med Rehabil 79:730-737, 1998

16. Henry PC, Hauber RP, Rice M: Factors associated with closed head injury in a pediatric population. J Neurosci Nurs 24: 311-316, 1992

17. Howell DC: Statistical Methods for Psychology, ed 4. Belmont, CA: Duxbury Press, 1997

18. Hulst LK, Fleishaker JC, Peters GR, et al: Effect of age and gender on tirilazad pharmacokinetics in humans. Clin Pharmacol Ther 55:378-384, 1994

19. Hyde JS, Linn MC: Gender differences in verbal ability: a metaanalysis. Psychol Bull 104:53-69, 1988

20. Jensen OK, Nielsen FF: The influence of sex and pre-traumatic headache on the incidence and severity of headache after head injury. Celphalgia 10:285-293, 1990

21. Kaplan CP, Corrigan JD: Effect of blood alcohol level on recovery from severe closed head injury. Brain Inj 6:337-349, 1992

22. Klauber MR, Marshall LF, Barrett-Connor E, et al: Prospective study of patients hospitalized with head injury in San Diego County, 1978. Neurosurgery 9:236-241, 1981

23. Kraus JF, McArthur DL, Silberman TA: Epidemiology of mild brain injury. Semin Neurol 14:1-7, 1994

24. Kraus JF, Nourjah P: The epidemiology of mild, uncomplicated brain injury. J Trauma 28:1637-1643, 1988

25. Kraus JF, Peek-Asa C, McArthur D: The independent effect of gender on outcomes following traumatic brain injury. Neurosurg Focus 8 (1):Article 4, 2000

26. Kraus JF, Sorenson SB: Epidemiology, in Silver JM, Yudofsky SC, Hales RE (eds): Neuropsychiatry of Traumatic Brain Injury. Washington, DC: American Psychiatric Press, 1994

27. Levin HS, Mattis S, Ruff RM, et al: Neurobehavioral outcome following minor head injury: a three-center study. J Neurosurg 66:234-243, 1987

28. Marshall LF, Maas AI, Marshall SB, et al: A multicenter trial on the efficacy of using tirilazad mesylate in cases of head injury. J Neurosurg 89:519-525, 1998

29. Marshall LF, Marshall SB, Musch B, et al: Outcome of moder- 
ate and severe head injury in patients treated with tirilazad mesylate. J Neurosurg 84:342A, 1996 (Abstract)

30. McMordie WR, Barker SL, Paolo TM: Return to work (RTW) after head injury. Brain Inj 4:57-69, 1990

31. Morrongiello BA, Rennie H: Why do boys engage in more risk taking than girls? The role of attributions, beliefs, and risk appraisals. J Pediatr Psychol 23:33-43, 1998

32. National Highway Traffic Safety Adminstration: National Occupant Safety Use Survey (NOPUS). Controlled Intersection Study. Washington, DC: Department of Transportation, 1997

33. Pentland B, Jones PA, Roy CW, et al: Head injury in the elderly. Age Ageing 15:193-202, 1986

34. Rivara JM, Jaffe KM, Polissar NL, et al: Predictors of family functioning and change 3 years after traumatic brain injury in children. Arch Phys Med Rehabil 77:754-764, 1996

35. Rimel RW, Giordani B, Barth JT, et al: Disability caused by minor head injury. Neurosurgery 9:221-228, 1981

36. Roof RL, Duvdevani R, Braswell L, et al: Progesterone facilitates cognitive recovery and reduces secondary neuronal loss caused by cortical contusion injury in male rats. Exp Neurol 129:64-69, 1994

37. Roof RL, Duvdevani R, Stein DG: Gender influences outcome of brain injury: progesterone plays a protective role. Brain Res 607:333-336, 1993

38. Rutherford WH: Sequelae of concussion caused by minor head injuries. Lancet 1:1-4, 1977

39. Sabhesan S, Natarajan M: Sexual behavior after head injury in Indian men and women. Arch Phys Med Rehabil 18:349-356, 1989

40. Schmidt ME, Matochik JA, Goldstein DS, et al: Gender differences in brain metabolic and plasma catecholamine responses to alpha2-adrenoreceptor blockade. Neuropscyhopharmacology 16:298-310, 1997

41. Shaywitz BA, Shaywtiz SE, Pugh KR, et al: Sex differences in the functional organization of the brain for language. Nature 373:607-609, 1995

42. Turkheimer E, Farace E: A reanalysis of gender differences in IQ scores following unilateral brain lesions. Psychol Assess 4: 498-501, 1992

43. Turkheimer E, Farace E, Yeo RA, et al: Quantitative analysis of gender differences in the effects of lateralized lesions on verbal and performance IQ. Intelligence 17:461-474, 1993

44. Webb CR, Wrigley M, Yoels W, et al: Explaining quality of life for persons with traumatic brain injuries 2 years after injury. Arch Phys Med Rehabil 76:1113-1119, 1995

45. Wilberger JE Jr, Harris M, Diamond DL: Acute subdural hematoma: morbidity and mortality related to timing of operative intervention. J Trauma 30:733-736, 1990

46. Williams JM, Gomes F, Drudge OW, et al: Predicting outcome from closed head injury by early assessment of trauma severeity. J Neurosurg 61:581-585, 1984

47. Wingard DL: The dex differential in morbidity, mortality, and lifestye. Ann Rev Publ Health 5:433-458, 1984

48. Zimbardo PG, Keough KA, Boyd KN: Present time perspective as a predictor of risky driving. Presonal Indiv Differ 23: 1007-1023, 1997

Manuscript received November 23, 1999.

Accepted in final form December 22, 1999.

Address reprint requests to: Elana Farace, Ph.D., Department of Neurosurgery, University of Virginia, Charlottesville, Virginia 22908. email: farace@ virginia.edu. 